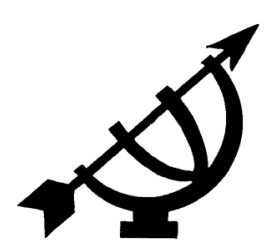

\title{
A consumer perspective on food labelling: ethical or not?
}

\author{
M. van der Merwe \& K. Venter \\ Department of Consumer Sciences \\ Potchefstroom Campus \\ North-West University \\ POTCHEFSTROOM \\ E-mail: daleen.vandermerwe@nwu.ac.za \\ venter.karin@gmail.com
}

\section{Abstract}

\section{A consumer perspective on food labelling: ethical or not?}

This article provides a review of ethical food labelling from a consumer perspective and makes recommendations to the food industry and regulators regarding ethical food labelling in order to satisfy consumers' food-labelling needs. Various studies have found that many consumers have negative perceptions regarding food labelling. However, research on consumers' perspectives regarding ethical food labelling has been accorded little attention. This article addresses this topic through a review of the relevant literature of mostly quantitative research, but also includes qualitative and mixed method studies. The article examines such aspects as the trustworthiness of claims on food labels, intelligibility of label information, listing of food additives on labels, and labelling of genetically modified foods. As negative perspectives on food labelling are likely to affect consumers' decision making regarding the purchasing of food products, the food industry must realise their responsibility to provide ethical food labels. The food industry and regulators should aim to provide risk communication and intelligible information through ethical food labels and consumer education programmes on food labelling. Consumers need to be aware of their right to know what they are purchasing through ethical food labels and take a stand in this regard. 


\section{Opsomming}

\section{'n Verbruikersperspektief op voedseletikettering: eties of nie?}

Hierdie artikel bied 'n oorsig oor etiese voedseletikettering vanuit 'n verbruikersperspektief en maak aanbevelings aan die voedselindustrie en -reguleerders rakende etiese voedseletikettering om verbruikers se voedseletiketteringsbehoeftes te bevredig. Verskeie studies het bevind dat verbruikers meestal negatiewe persepsies ten opsigte van voedseletikettering het. Min aandag word egter geskenk aan navorsing aangaande verbruikers se perspektiewe oor etiese voedseletikettering. Hierdie onderwerp word in dié artikel aangesny deur middel van 'n oorsig van die betrokke literatuur van meestal kwantitatiewe navorsing, maar ook van kwalitatiewe en gemengde-metode studies. Aspekte soos die betroubaarheid van aansprake op voedseletikette, verstaanbaarheid van voedseletiketinligting, 'n lys van voedseladditiewe op etikette, en etikettering van geneties-gemodifiseerde voedsel word ondersoek. Aangesien negatiewe persepsies van voedseletikettering moontlik ook 'n impak op verbruikers se besluitneming ten opsigte van die aankoop van voedselprodukte mag hê, sal die voedselreguleerders en die voedselindustrie hulle verantwoordelikheid moet besef om etiese voedseletikette te voorsien. Die voedselindustrie en -reguleerders moet daarna streef om risikokommunikasie en verstaanbare inligting deur etiese voedseletikette asook verbruikersopleidingsprogramme oor voedseletikettering te voorsien. Verbruikers moet bewus wees van hulle reg om te weet wat hulle koop deur etiese voedseletikette en behoort standpunt in hierdie verband te kan inneem.

\section{Introduction}

Advances in food production and processing have resulted in consumers eating more processed food (Davies, 2000:2; Schlosser, 2002) making it more difficult to know the composition of the food they are consuming. Consumers' concerns regarding this, as well as their avoidance of food-borne pathogens, toxins (Liakopoulos \& Schroeder, 2003:42) and allergens (Liakopoulos \& Schroeder, 2003:42; Voordouw et al., 2009:94) are increasingly taken into consideration when making food purchasing decisions. Hence, it is becoming increasingly important for consumers to be able to determine the ingredients (Davies, 2000:2) and nutritional value of the food they consume (Davies, 2000:2; Cowburn \& Stockley, 2005:22; Dimara \& Skuras, 2005:96).

The food label is one source of information consumers use to acquire knowledge about food items (Wandel, 1997:212; Dimara \& 
Skuras, 2005:90), in order to make decisions regarding food purchases that are less uncertain (Silayoi \& Speece, 2004:624) and more informed (Davies, 2000:2). Labels assist the consumer in determining the nutritional value (Wandel, 1997:213; Higginson et al., 2002:95) and ingredients of food (Wandel, 1997:213). Furthermore, accurate and dependable food label information is of special importance to those avoiding certain ingredients for religious, ethical (Davies, 2000:2) or allergy reasons (Abbott, 2004:S345; Voordouw et al., 2009:94).

Health conscious consumers are dependent on food label information to assist them in protecting their health, often by complying with the dietary guidelines set out by health authorities (Byrd-Bredbenner et al., 2000:615) and making healthy food choices (Sijtsema et al., 2002:572; Dimara \& Skuras, 2005:91). As their health is the foremost reason for consumers' use of food labels (Wandel, 1997:212), the availability of comprehensive, intelligible, accurate and truthful nutritional information on food labels (Davies, 2000:3) is essential to consumers.

Food labels may contain health claims, indicating the relationship between specific nutrients and diseases or health conditions (Wilkening, 1996:10; SA, 2007:76), as well as nutrient content and function claims. Nutrient content claims describe the amount of a nutrient present in food, whereas function claims illustrate the claimed physiological role of a certain nutrient or substance in development, growth and other functions of the body (SA, 2007:76, 78). These claims appear on the front of packaging, which makes the label information more clearly visible and thus accessible to consumers (Keller et al., 1997:257).

In addition to the above, food labels should list the main ingredients, additives and condiments added to food (Wandel, 1997:212), as well as aspects such as geographic origin (Dimara \& Skuras, 2005:90) and quality of the ingredients (Nilsson et al., 2003:517; Dimara \& Skuras, 2005:90), in order to be more informative to the consumer. Such a wealth of information on food labels would allow health conscious consumers to make the most suitable choices for their health and nutritional needs.

As food labelling serves as information source in the consumer decision making process, proper nutrition labelling could increase the demand for healthy products, stimulate product competition based on nutritional quality, and motivate the development and production of foods with enhanced nutritional properties (Baltas, 2001:708). 
Moreover, it could offer a health and medical cost benefit in terms of the potentially reduced prevalence of coronary heart disease and cancer among consumers (Wilkening, 1996:10), thereby promoting and protecting public health (Anon., 2004:146). It is therefore clear that proper nutrition labelling and substantiated claims offer more benefits to the consumer than the mere provision of nutritional information.

Besides providing information to allow the consumer to make suitable food choices (McLaren, 1995:3; Abbott, 1997:44), food labelling serves as a marketing tool (Anon., 1996:10; Wright, 1997:421; Keller et al., 1997:257) that influences consumer needs and beliefs regarding the advertised product's benefits (Parker \& Penfield, 2005: S553). It is not clear that this marketing tool is always used ethically with the benefit of the consumer in mind. Does the consumer, who is dependent on this information to make an informed decision, perceive label information to be ethical?

The term ethical is defined as related to beliefs of what is right or wrong or morally acceptable (Hornby, 2005:498). The present article examines the moral acceptability of the way that food is labelled, from the consumer's perspective, in order to answer the question posed above. The objectives are in the first place to establish consumers' perspectives on ethical food labelling and secondly to examine the roles the food industry, food regulators and consumers play with regard to ethical food labelling. Based on this, consumers' trust in the food industry and regulators, and the impact that ethical food labelling would have on the consumers' decision making processes, are discussed.

\section{Application of food ethics to food labelling}

Ethics is defined as the morals that persons or entities apply to their behaviour (Hornby, 2005:498). Thus, food ethics determines the behaviour of various entities in the food industry, such as producers, manufacturers and retailers, and regulators. Food ethics is a discipline within the field of Applied Ethics that attempts to apply ethical theory to foods. It is an important concern to consumers, as food directly affects their physical, biological, cultural and social environments (Mepham, 2000:610). Furthermore, consumers are becoming increasingly dependent on the food industry and consequently expect the industry to place their interests and rights foremost in the provision of food (Early, 2002:340). Therefore, striving towards increased sales while attempting to behave ethically to- 
wards consumers may cause the food industry a conflict of interests (Early, 2002:340).

Food ethics is related to issues of trust of food manufacturers and retailers. Trust is defined as the belief that persons or entities are good, sincere or honest, while trustworthy implies persons or entities that have these values (Hornby, 2005:1586). Consumers who trust food suppliers, such as restaurants or retailers, place themselves at risk of being exploited (Early, 2002:340). Consumers may feel that they cannot trust the food industry (Bromley, 2001; Croft, 2004:38), particularly once cases of deliberate distortion of facts become known (Frewer et al., 1996:483). For example, a Finnish study on ethical consumerism found that only $2,1 \%$ of respondents regarded information provided by firms as highly trustworthy (Uusitalo \& Oksanen, 2004:217). This illustrates the powerful influence that the food industry's unethical trade can have on consumers' opinions thereof and the subsequent detrimental influence on their purchasing behaviour. In addition, the increasing number of food scares in European food markets has eroded consumer trust in the food industry and its role players (Grunert, 2002:285). Nevertheless, consumers expect retailers to assist them in their efforts to follow a healthy diet (Croft, 2004:38). This assistance could be provided through ethical food labelling.

\section{Consumer perspectives on ethical food labelling}

The following ethical issues are pertinent to food ethics and food labelling from the perspective of consumers: trustworthiness of claims on food labels, intelligibility of label information, listing of food additives on labels and labelling of genetically modified (GM) foods. These pertinent issues are discussed in the sections that follow.

\subsection{Trustworthiness of claims on food labels}

Trust is built on a large number of positive incidents, but is destroyed by a relatively small number of negative incidents (Liakopoulos \& Schroeder, 2003:45). It is based on the trustee (in this case the food industry and regulators) fulfilling consumers' expectations. During times of uncertainty, trust becomes essential. In the context of the present article, this implies that food manufacturers and retailers have to meet the expectations of consumers before they will trust claims made on food labels. Trust in these entities is particularly relevant in a situation in which the consumer is unsure about the food product and depends on label information and claims in order to make a product purchase. 
Trust is linked to perceptions of accuracy, knowledge (Frewer et al., 1996:483) and concern with public welfare (Frewer et al., 1996:483; Uusitalo \& Oksanen, 2004:214, 215). Thus, consumers expect that, as part of their corporate social responsibility, companies (such as food manufacturers and retailers) will follow laws and ethical norms (Mohr et al., 2001:47). This implies that consumers will trust the claims of law-obeying food manufacturers if they perceive this entity as a source of accurate information. Consumers expect food labels to disclose the facts about products, in order to facilitate informed decisions (Croft, 2004:40). They often consider the credibility of food labels more important than the amount of information supplied on labels (Zadek et al., 1998:19; De Pelsmacker et al., 2005:523). Consumers acquire nutritional information from the nutrition facts panel, nutrient content claims and health claims on labels (Andrews et al., 2009:42), expecting that particularly the latter will be trustworthy (Davies, 2000:7; Croft, 2004:40). Yet, one reason for consumers' non-use of labels is a lack of trust in the entity supplying the product and, therefore, a lack of trust in the accuracy of the food label information (Cowburn \& Stockley, 2005:26).

In order to ensure that health, nutrient content and function claims on food labels are trustworthy, strict food labelling regulations control the use thereof in South Africa and internationally through recently revised regulations. The United States Food and Drug Administration (USFDA) issued strict new regulations that aim to ensure that consumers are provided with trustworthy nutritional information on all food labels, in order to facilitate their food choices for a healthy diet (Petruccelli, 1996:150; Wilkening, 1996:10) and reduce consumer confusion (Petruccelli, 1996:150). These regulations guide the standardisation of food labelling regarding the nutrition facts panel (Silverglade, 1996:148; Garretson \& Burton, 2000:213). The regulations were effected following the endorsement of the Nutrition Labelling and Education Act (NLEA) effective from May 1994 (Ford et al., 1996:16) and could serve as an example for labelling regulations in other countries (Drichoutis et al., 2006:ii; Turner, 2007:167). Both health and nutrient content claims are strictly regulated by the USFDA (Wilkening, 1996:10; Drichoutis et al., 2006:8), whereas food manufacturers are permitted to use function claims in a truthful manner in conjunction with a disclaimer of not being USFDA evaluated (USFDA, 2001). Prior to these new regulations, misleading claims often caused consumer confusion, for example the term "light" cheesecake (Silverglade, 1996:148) incorrectly indicates a cheesecake low in fat, while "light" and "low" also have a different meaning on different products (Petruccelli, 1996:150). The 
United Kingdom (UK) regulations amended in 2004 to the UK Food Safety Act of 1990 prohibit misleading food labelling in the UK (FSA, 2004:4).

It is evident that considerable effort has been administered internationally to improve labelling and the trustworthiness of claims. In South Africa, a draft of the newly revised South African Labelling Regulations (R642) was released for public inspection in 2007 (SA, 2007). These regulations aim to reduce ambiguity in the existing regulations (R2034) of 1993 (Booysen, 2007:55) and to prevent misleading label information, in order to protect consumers (Macanda, 2005). Under the revised regulations, all health, nutrient content and function claims will be regulated (SA, 2007:99, 101, 109).

These efforts by food regulators internationally and in South Africa to improve the trustworthiness of food labelling are encouraging from a health perspective, because more accurate label information would benefit not only the consumer, but also society in general (Wang et al., 1995:368, 379; Department of Health, 2007). However, until the new South African regulations of 2007 are promulgated, the 1993 regulations still apply. These regulations permit misleading label information, such as claims of "natural" and "low fat", which may be incorrectly interpreted by consumers as implying "healthy" (Macanda, 2005). Such claims cannot be regarded as trustworthy and the use thereof to mislead consumers in order to increase sales, is unethical.

South African research indicates that health and nutrient content claims serve as a valuable source of information on food, influencing the purchasing behaviour of some consumers (Klein, 2005:99). This was found to apply particularly to consumers with a lower level of education, who pay more attention to the front, claim-bearing panel on labels (Drichoutis et al., 2006:13). European studies indicate that some consumers experience health claims positively, increasing their trust in a product (Liakopoulos \& Schroeder, 2003:47), whereas US studies indicate that health claims have no effect on perceived nutritional value (Ford et al., 1996:24; Keller et al., 1997:265) and thus product trust. This is because US consumers are sceptical regarding health and nutrient content claims (Garretson \& Burton, 2000:214), believing that manufacturers use these claims for product promotion (Keller et al., 1997:257) and thus the information provided might be untrustworthy and unethical. Furthermore, US consumers tend to view nutritional information as more trustworthy than health claims (Keller et al., 1997:266; Garretson \& Burton, 2000:220). Such consumers may not be aware that the US regu- 
lations based on the NLEA developed standards for all health and nutrition claims for foods (Silverglade, 1996:148) that specify the approved label claims permitted and the specific conditions these claims must adhere to in order to be approved (Keller et al., 1997:256).

Belgian (Liakopoulos \& Schroeder, 2003:47) and South African (Klein, 2005:100) studies investigating the concerns and suspicions of consumers regarding the trustworthiness of health claims indicate that consumers are uneasy about claims that they cannot verify. Consumers might, therefore, view the usage of claims on labels as unethical.

The issues of trustworthiness surrounding claims on labels are of concern, as these claims are intended to improve the health of consumers. It could be asked how consumers can be expected to trust a product to improve their health when the claim is not regarded as trustworthy. Also of concern is that consumers with a lower level of education are at increased risk of exploitation by untrustworthy claims or claims intended for promotional benefit only. It is likely that the low level of education of a large percentage of the South African population places them at risk of exploitation and misunderstanding label claims. However, it is encouraging that considerable effort has been made to improve food labelling regulations internationally and in South Africa in order to prevent misleading claims and thus the exploitation of consumers. In South Africa the revised regulations are aimed at addressing previous ambiguities in regulations that inadvertently permitted and may still permit unethical labelling.

\subsection{Intelligibility of food label information}

In order for consumers to be able to use food label information valuably, information needs to be presented in an intelligible way (Wandel, 1997:212; Flowerdew, 2000:65). French (Mannell et al., 2006:166) and South African (Klein, 2005:102) studies indicate that consumers often find the information on labels difficult to understand, owing to the specialist technical terminology used. A systematic review by Cowburn and Stockley (2005:23) confirms that the technical and numerical information provided confuses consumers, even though they might understand the nutritional information. Owing to the confusion caused by such jargoned terminology, parents of children with allergies in a US study (Joshi et al., 2002: 1021) failed to identify food allergens correctly as indicated on the label. 
Consumers' difficulties regarding the understanding of nutritional information provided (Baltas, 2001:712; Mannell et al., 2006:162) are aggravated by small printing on food labels (Klein, 2005:102; Mannell, 2006:160) or information that is difficult to locate on the label (Mannell et al., 2006:160). Studies in the United Kingdom (Abbott, 1997:47; Croft, 2004:40) and Norway (Wandel, 1997:214) confirm that in order to make meaningful use of labels, the average consumer desires intelligible labels.

Fortunately, consumers do not always find labels difficult to understand and regulations may indeed be effecting positive changes in this regard. Participants in a South African study found labels to be more intelligible than they had been in the past (Klein, 2005:101). Hopefully, enforcement of the draft revised food labelling regulations in South Africa (SA, 2007) will render food labels even more intelligible.

It is of concern that despite international efforts by food regulators to improve labelling regulations and thereby prevent consumers from being misled, many consumers still find labels difficult to understand. A label that is incomprehensible to consumers can be considered unethical. However, such a lack of understanding could perhaps also be attributed in some instances to a lack of nutritional knowledge on the part of the consumer. Nevertheless, poor education, particularly in a country such as South Africa, should not be exploited by food manufacturers by using specialist terminology and a label format that the average consumer is likely not to understand. The education level of the average consumer must be considered when compiling food labels.

\subsection{Listing of food additives on labels}

In a study by Wandel (1997:215), 60\% of the respondents who read labels paid particular attention to food additives, which indicates the importance of this information to consumers. Studies in the United Kingdom (Abbott, 1997:47), Norway (Wandel, 1997:213) and South Africa (Dicks, 2007:188) indicate that many consumers are unable to identify the additives listed on labels correctly. A number of consumers also find the $E$ numbers used to indicate food additives difficult to understand (Wandel, 1997:214; Dicks, 2007:196). Only $34 \%$ of consumers in Przyrembel's (2004:361) study in the European Union were aware that these numbers refer to additives. However, of the respondents in Abbott's (1997:45) study 65,5\% knew that $E$ numbers refer to food additives. Furthermore, they associate these with dangerous allergy-aggravating or carcinogenic 
effects (Abbott, 1997:45; Wandel, 1997:214). Several consumers in Dicks' (2007:208) study even associated E numbers with GM food. Thus, it is evident that food-additive labelling issues can lead to consumer doubts regarding the safety of food products (Wandel, 1997:218).

Consumers' negative perceptions regarding $E$ numbers are often the result of misconceptions about these numbers (Wandel, 1997:214). Because of these misconceptions, some consumers feel that these numbers are misleading and should be replaced by actual additive names. This situation is ironic, as these numbers were originally developed to simplify food labelling (Wandel, 1997:218, 219).

The revised draft of South African regulations (SA, 2007) will strictly regulate the labelling of food additives according to the guidelines developed by the Codex Alimentarius Commission of the Food and Agriculture Organisation of the United Nations and the World Health Organisation, which stipulates international food safety regulations. Under the draft revised regulations, the common chemical additive name is required on the label. However, the use of $E$ numbers is not mentioned. Consumers in Dicks' (2007:279) study raise concerns regarding the lack of standardised terminology, illegible listing of additives, insufficient and untrustworthy information, manufacturer dishonesty and a lack of regulation of additives. Even though insufficient general knowledge of food additive labelling may partly explain these negative perceptions, it can be concluded that these consumers have found current food additive labelling under the 1993 regulations in South Africa unethical. Furthermore, it is doubtful whether the average South African consumer will understand even the common chemical names of additives as required by the draft revised regulations, which again stresses the importance of consumer education in South Africa.

\subsection{Labelling of genetically modified (GM) food}

Consumers' concerns regarding the use of GM foods are mainly about the quality and trustworthiness of the product (Bredahl, 2001:47), but they also have environmental, health-related, ethical and religious concerns (Kaufman, 2001) which results in different consumer opinions about these products (Radas et al., 2008:356). Whereas some might reject all GM products regardless of potential benefits (Bredahl, 2001:53; Radas et al., 2008:356), others accept such products or assume a neutral stance regarding these (Radas et al., 2008:356). The trustworthiness of the product is related to perceived consequences of using GM technology to create a food 
product (Bredahl, 2001:43). For instance, the mandatory labelling requirements for GM foods in the European Union led to the removal of these products from the shelves for fear of consumer rejection owing to negative perceptions (Carter \& Gruère, 2003:68).

Ethical issues regarding the labelling of GM foods are mostly linked to the amount of information supplied and the way in which it is presented on the label (Teisl et al., 2002:6). In this regard, Frewer et al. (1996:476) found information about genetic engineering of foods to be one of the most distrusted types of information according to United Kingdom consumers.

While European regulations require mandatory labelling of products containing GM ingredients (Teisl et al., 2002:7; Scholder Ellen \& Fitzgerald Bone, 2008:69), US and South African regulations only require labelling of certain ingredients in products (such as allergens) and in instances in which the GM product differs significantly from the non-GM equivalent (Bickford \& Mabiletsa, 2006:6; Scholder Ellen \& Fitzgerald Bone, 2008:69). European GM labelling regulations were revised to include most food products containing GM ingredients at lower threshold levels than before (Carter \& Gruère, 2003:68), but US (Radas et al., 2008:352) and South African (Botha \& Viljoen, 2009:1060) regulations permit voluntary labelling of food products containing GM ingredients. This might cause consumers to believe that food products do not contain GM ingredients, because their labels do not indicate this, when that may actually not be the case. Davies (2000:4) and Kaufman (2001) find that consumers who are familiar with GM products wish for all GM derivatives to be labelled. Similarly, the majority of consumers in US studies conducted, felt that they have a right to know what they are purchasing and consuming and that the labelling of all GM ingredients, even at low levels, should be mandatory (Teisl et al., 2002:7; Radas et al., 2008:352).

Legislation in South Africa, and other countries, permits food labels to contain a "GMO-free" or "non-GM" claim. These terms indicate low levels of GM ingredients or the absence thereof (Viljoen et al., 2006:75). While various countries define different threshold levels within which the "GMO-free" claim is permitted, South Africa has no restrictions regarding this, as GM labelling is voluntary (Viljoen et al., 2006:75, 76). A "GMO-free" claim may cause considerable confusion and scepticism among consumers (Teisl et al., 2002:7). While some consumers view labels containing such claims as insufficient for informing their decision making (Teisl et al., 2002:7), others logically assume that the label implies the absence of GM ingre- 
dients in the product (USFDA, 2001; Teisl et al., 2002:7). Since these products are permitted to contain low levels of GM ingredients (and unmonitored levels in the case of South Africa), consumers are misled by the claim bearing the word free. Thus, the "GM-free" claim may be viewed by some consumers as unethical.

It is evident that insufficient research in a South African context on consumers' perceptions of GM labelling has been conducted. That such research is crucial is evident from international concerns about the labelling of such foods, particularly in the US, with regard to insufficiently strict regulation. Genetic modification of food is a controversial subject owing to its link to a consumer's personal belief system regarding genetic engineering. Thus, withholding information about food products containing GM ingredients can be regarded as unethical.

\section{Responsibility of the food industry and regulators regarding ethical food labelling}

Mepham (2000:611) suggests that the application of food ethics to food provision is not only determined by government policy, as private companies can also play a significant role in shaping food provision. Companies could indicate more visibly that they follow ethical codes of conduct by, for instance, using food labels to differentiate themselves from their competitors in this regard (Uusitalo \& Oksanen, 2004:220). Recent developments in ethical food labelling such as fair trade, social, bio- and eco-labels (De Pelsmacker et al., 2005) provide the perfect opportunity to effect such differentiation.

Despite the contribution that the food industry can make to food ethics, food regulators ultimately decide upon and enforce legislation (Mepham, 2000:611). Focus group discussions with US respondents found that consumers believe that the USFDA or the American Cancer Society is responsible for monitoring the labelling of GM foods (Teisl et al., 2002:8). The efforts of various regulators to improve food labelling regulations to benefit the consumer bear testimony that they are realising their responsibility regarding the provision of ethical food labelling. Three ways in which the food industry and regulators could improve food labelling from an ethical perspective is through risk communication, intelligible information provision and consumer education on food labelling, which is discussed in the sections that follow. 


\subsection{Risk communication through labelling}

Consumers often experience uncertainty when they cannot anticipate the consequences of their purchasing actions; this is known as their perceived risk (Schiffman \& Kanuk, 2009:188). In order to reduce this risk, a search for information regarding the product is a strategy consumers use. A risk is often perceived as less serious if a consumer can control it (Renn, 2005:1062). Food labelling information as information source can therefore play an invaluable role in consumers' decision making regarding food products, thereby reducing their perceived risk.

A practical example of improved risk communication through labelling is consumer research regarding food allergy concerns that enabled Food Standards Australia New Zealand to introduce improved labelling legislation (Abbott, 2004). This legislation makes labelling of allergy- or intolerance-causing foods or substances present in a product mandatory, irrespective of the amount present. In this regard, the Codex Alimentarius Commission developed a list of allergens that have to be declared on food labels. Most of the current food-labelling legislation in the US and Europe and the draft revised regulations in South Africa aim for a more consistent approach regarding food-allergen labelling. The use of intelligible terminology and a labelling format that states potential health risks clearly to consumers facilitates more effective risk communication and makes labelling more ethical.

\subsection{Intelligible information provision through labelling}

As with risk communication through labelling, intelligible information provision is the responsibility of the food industry and regulators. As mentioned, consumers often find food labels difficult to understand. The technical terminology used, prevents consumers from making informed purchasing decisions. An example of this is the association of sodium with salt, which consumers find difficult to understand (Cowburn \& Stockley, 2005:23). The draft revised regulations make provision for the usage of more commonly used words such as salt instead of sodium chloride (SA, 2007:91), which might aid consumers in ingredient comprehension.

Consumers have the right to choose to consume or avoid whatever ingredients they wish (Davies, 2000:2). The draft revised South African regulations propose that ingredients occurring in quantities constituting less than $5 \%$ of the product content be omitted from the food label, except for common allergens and food additives that 
must be labelled (SA, 2007:91). Even though United Kingdom regulations stipulate a lower value of 2\% (Przyrembel, 2004:361), the ethical standard of both these regulations is debatable as consumers should have the right to be aware of all the ingredients they are consuming, including those present in amounts lower than $2 \%$.

Besides the mere provision of information required by legislation, such as ingredients and nutritional information, nutritional information should also be comparable between products. Consumers often find it difficult to compare nutritional information expressed in grams per $100 \mathrm{~g}$ to grams per serving (Cowburn \& Stockley, 2005: 23). The draft revised regulations require both formats to be provided (SA, 2007:130) in order to assist the consumers in comparing similar products. In this way, South African regulators are attempting to provide intelligible label information to empower consumers in making purchasing decisions.

The food industry and regulators could further assist consumers in the provision of intelligible information on nutrition labels by providing an interpretation of the information provided or benchmark values against which to measure numbers appearing on the label (Davies, 2000:4; Cowburn \& Stockley, 2005:26). In this regard, the use of simple descriptors, such as high, medium and low (Shannon, 1993:42) could be valuable. Traffic-light labelling, which indicates foods containing high, medium or low fat, sugar or salt levels using red, amber or green colours, also facilitates consumers' judgement of the nutritional quality of foods (Lindley, 2007:79). This last labelling type appears to be consumers' preferred format (Drichoutis et al., 2006:12). In a South African study (Klein, 2005:104), consumers encouraged the use of symbols showing the endorsement of a product by an authoritative institution. Such endorsement would lend credibility to a food product, thereby resulting in a higher sense of security and thus reduced perceived risk.

Addressing the problem of consumers' lack of understanding of food label information needs to be a two-step process. Firstly, consumer education on food labelling should be a priority, particularly in a country such as South Africa where a lack of consumer education exposes consumers to misinterpretation of label information and exploitation. Secondly, regulating authorities should strive towards mandating labelling regulations that require a simpler format for label information that consumers can better understand. 


\subsection{Consumer education on food labelling}

Research indicates that consumers who are less informed regarding food labelling prefer a small amount of simple information on food labels (McCullough \& Best, 1980:191). Furthermore, the more informed consumers are about food labelling aspects, such as the interpretation of nutritional information, the fewer misconceptions may occur in this regard (Mazis \& Raymond, 1997:23). Consumers require assistance in distinguishing between accurate information and false or misleading information (Abbott, 1997:43). Therefore, as emphasised throughout this article, there is a need for more consumer education programmes on food labelling in order for consumers to understand food labelling information better and use it correctly in their decision making when purchasing food products. Unfortunately, little is known about the nature of education programmes that would benefit consumers' understanding of nutritional information on labels (Cowburn \& Stockley, 2005:27). Since it has been proven that educated consumers more often use label information (Wandel, 1997:212; Drichoutis et al., 2006:2), these education programmes could focus on the uninformed and less educated consumers, particularly in the South African context.

\section{Consumers' trust in the food industry and regulators with regard to ethical food labelling}

From the previous sections, it is evident that consumers often have low levels of trust in food labelling information, which will hinder consumer trust in food regulators and other key players in the food industry. Liakopoulos and Schroeder (2003:48) confirm the prevalence of declining consumer trust in governments, public institutions and official decision making authorities. This distrust is concerning as food labelling in South Africa is regulated and decided upon by the Department of Health, while food manufacturers ultimately decide how to apply the labelling regulations to their products.

In a UK study, consumers rated the food industry high on accountability and self-protection, but lower on trustworthiness and knowledge (Frewer et al., 1996:483). In order for the food industry to regain the trust of the consumer, entities need to provide independent, transparent and holistic risk communication (Liakopoulos \& Schroeder, 2003:51). This can be achieved by food manufacturers through the use of intelligible and trustworthy food labels that will be considered ethical by consumers. Food regulators need to apply these same principles and realise their responsibility towards consumers by drawing up and enforcing strict legislation to regulate 
food labelling and thereby prohibiting food manufacturers from providing unethical food labels.

\section{Consumers' rights and responsibilities with regard to ethical food labelling}

It is important to realise that the industrial activities of food and agriculture filter through to consumers' physical, biological, social and cultural environment to a greater extent than those of other industries (Mepham, 2000:610). Therefore, food ethics is a critical aspect when consumer rights are considered, particularly because modern consumers are more educated, informed (Uusitalo \& Oksanen, 2004:215), sophisticated (Carrigan \& Attalla, 2001:571; Turner, 2007:166) and aware of their rights and responsibilities (Uusitalo \& Oksanen, 2004:215). Moreover, they are more aware of the link between food and health (Turner, 2007:166) and the relevance of this to the information appearing on food labels (Brennan et al., 2008:57). Consumers' most basic right with regard to food labelling is to know what they are consuming. However, the rights and responsibilities of consumers to improve ethical food labelling need to be considered too.

Ethical consumer behaviour is an aspect of growing significance for industry and consumers alike in many countries (De Pelsmacker et al., 2005:513). Unfortunately, consumers in a Finnish study appear to lack confidence in their ability to promote ethical trade and feel that they are not given sufficient opportunity to practise ethical consumerism (Uusitalo \& Oksanen, 2004:217). Similarly, consumers might lack confidence in their right to encourage ethical food labelling, where the government acts as the regulator that determines legislation, giving consumers few opportunities to provide input. Yet, pressure from consumer groups led to the withdrawal of health claims from the products of two US companies, stressing the responsibility of consumers to make their voices heard (Mazis \& Raymond, 1997:24). Through ethical purchasing behaviour, consumers can express their approval and support of organisations that act socially and environmentally responsible (De Pelsmacker et al., 2005:512). Likewise, by not making a purchase based on ethical grounds surrounding food labelling, consumers can enforce their right to choose what they wish to consume. Such actions could put further pressure on the food industry and regulators to invest in ethical food labelling. 


\section{Influence of the ethical issues regarding food labelling on consumers' decision making}

Food labelling as source of consumer information has been discussed throughout this article, yet it should be noted that not all consumers regard food labels as important. For instance, $51 \%$ of South Africans rarely or never read food labels (Macanda, 2005). For those consumers who regard label information as important, such information exerts a significant influence on consumers' decision making process (Wright, 1997:421) and thus their purchasing decisions (Silayoi \& Speece, 2004:624), particularly in the case of health conscious consumers (Balasubramanian \& Cole, 2002:122; Klein, 2005:104). A South African study indicates that participants who are sometimes influenced by labels react as a result of situational factors, such as the price and the taste of the product (Klein, 2005:104). Although the purchasing behaviour of some consumers is not influenced by labelling information at all (Klein, 2005: 100 ), it is evident that food label information is a critical determinant of many consumers' purchasing decisions, particularly through the provision of diet-related (Drichoutis et al., 2006:1, 14) and qualityrelated information (Dimara \& Skuras, 2005:92).

In order for consumers to purchase ethically acceptable products, much effort is necessary on their part with regard to the acquisition of information and the decision making process itself (Uusitalo \& Oksanen, 2004:217). Consumers can only make a meaningful decision on what to purchase when equipped with relevant and comprehensive information (Shannon, 1993:44; Lazarowicz, 2005). Thus, it is suggested that labels should aid consumers in identifying ethical food products without being required to search through a great deal of unintelligible information (De Pelsmacker et al., 2005:516). A Norwegian study found that only $23 \%$ of respondents feel that they have sufficient information to make fully informed decisions when purchasing food (Wandel, 1997:214). Furthermore, owing to the difficulty that many consumers have in interpreting nutritional information on food labels, their decision making process could be influenced when purchasing products (Baltas, 2001:712). Lindley (2007:74) adds that incomplete, unclear or complex information may be regarded as imperfect information upon which to base a decision, which might result in a negative response to the food product and thus negatively affect purchasing behaviour from the perspective of food retailers. Thus, the perception of unethical food labelling could complicate the decision making process regarding food products, since consumers use food labels as an information source during 
the decision making process. Unethical food labelling might also result in consumers purchasing products based on insufficient information (and thus potentially to their detriment), or not purchasing anything at all. In instances in which a variety of product choices are available, ethical criteria may be used habitually in decision making (Shaw \& Clarke, 1999:115). Therefore, in order to allow consumers to make informed decisions, the food industry and regulators should accept the responsibility to enforce and provide ethical food labelling (Lazarowicz, 2005), or risk losing purchases altogether.

In this regard, the label should be viewed by food manufacturers as a marketing tool (Wright, 1997:421) used to make the consumer aware of new products or products with added benefits (Parker \& Penfield, 2005:S553). However, it is important that marketing be done ethically, providing consumers with sufficient information on which to base their purchasing decisions. Parker and Penfield (2005:S557) find that the label of the product affected the perceptions of panellists regarding an ice cream product, illustrating the powerful effect that labelling as a marketing tool may have on consumers' behaviour. A focus group discussion had similar findings: consumers perceived products with a health claim to be more tasty and wholesome compared to products without the health claim (Liakopoulos \& Schroeder, 2003:47).

Food labelling could be more effectively used in consumer decision making by educating consumers about food and nutrition, because consumers often have insufficient knowledge about healthy food and nutrition to make informed purchasing decisions (Lazarowicz, 2005). In addition, educational programmes should educate consumers on interpreting technical label terminology and layout and to practically apply it in decision making, because consumers have difficulty in understanding such information.

\section{Conclusion}

Considerable effort has recently been made by food regulators internationally and in South Africa to improve food labelling regulations and thereby to reduce misleading label information. Despite this, international research indicates that many consumers do not trust claims made on labels and find label information difficult to understand. International consumer perspectives cannot necessarily be extrapolated to the South African environment. However, it is doubtful that consumers in South Africa, where the draft revised regulations have not yet been promulgated, will experience labelling more 
positively than international consumers. The generally low education levels of South African consumers pose a further problem, as even the new regulations may result in unintelligible labels that consumers may find difficult to use in their food decision making processes.

A further problem regarding ethical labelling in South Africa is the voluntary labelling of GM food. By not disclosing all GM ingredients, consumers' right to decide what they consume is violated, as they are not provided with sufficient information to permit them to make an informed decision when purchasing such products. While it is evident that food regulators are realising their responsibility regarding ethical food labelling in South Africa, legislation gaps as typified by the lack of mandatory GM labelling regulations continue to allow food manufacturers to mislead consumers.

In addition to the efforts by food regulators in South Africa to make labelling more ethical through legislation, there is a need for the provision of consumer education regarding nutrition, food labelling and the practical usage of labels to enable informed decisions. Moreover, the food industry and regulators should provide label information in terminology and a label format that is easier for consumers to understand and use. Consumers too should realise their rights and responsibilities regarding ethical food labelling and ethical consumer behaviour and they should enforce these by not supporting manufacturers that fail to provide ethical label information.

The literature review provided by this article could form the basis for empirical research on consumers' expectations with regard to ethical food labels. Such information could assist the food industry and regulators in their efforts to provide food labels that are more ethical and thereby satisfy consumer needs and expectations.

\section{List of references}

ABBOTT, P. 2004. Australia/New Zealand approach to food allergens. Journal of food science, 69(4):S345-S346.

ABBOTT, R. 1997. Food and nutrition information: a study of sources, uses, and understanding. British food journal, 99(2):43-49.

ANDREWS, J.C., NETEMEYER, R.G. \& BURTON, S. 2009. The nutrition elite: do only the highest levels of caloric knowledge, obesity knowledge, and motivation matter in processing nutrition ad claims and disclosures? Journal of public policy and marketing, 28(1):41-55.

ANON. 1996. Health and nutrition claims in food labelling. Food industries of South Africa: 9-10, Jan. 
ANON. 2004. Encouraging consumer use of food label information needs innovative approaches. Cardiovascular week: 146, 15 Nov.

BALASUBRAMANIAN, S.K. \& COLE, C. 2002. Consumers' search and use of nutrition information: the challenge and promise of the Nutrition Labeling and Education Act. Journal of marketing, 66(3):112-127.

BALTAS, G. 2001. Nutrition labelling: issues and policies. European journal of marketing, 35(5 \& 6):708-721.

BICKFORD, R. \& MABILETSA, P. 2006. Republic of South Africa: food and agricultural import regulations and standards. Country report 2006. (Gain report no. SF6027.) http://www.fas.usda.gov/GainFiles/2006/07/1462083 37.pdf Date of access: 5 Jun. 2009.

BOOYSEN, A. 2007. New draft food labelling regulations, R642. Regulations relating to the labelling and advertising of foodstuffs. Papers read at the 19th Biannual Congress of South African Association for Food Science and Technology held in Durban on 2 to 5 September 2007. p. 55.

BOTHA, G.M. \& VILJOEN, C.D. 2009. South Africa: a case study for voluntary GM labelling. Food chemistry, 112:1060-1064.

BREDAHL, L. 2001. Determinants of consumer attitudes and purchase intentions with regard to genetically modified foods: results of a crossnational survey. Journal of consumer policy, 24(1):23-61.

BRENNAN, R., CZARNECKA, B., DAHL, S., EAGLE, L. \& MOUROTI, O. 2008. Regulation of nutrition and health claims in advertising. Journal of advertising research: 57-70, March.

BROMLEY, D. 2001. Mad cows, drugged cows, and juggled genes. Choices, 16:6-9, 2nd quarter.

BYRD-BREDBENNER, C., WONG, A. \& COTTEE, P. 2000. Consumer understanding of US and EU nutrition labels. British food journal, 102(8):615-629.

CARRIGAN, M. \& ATTALLA, A. 2001. The myth of the ethical consumer: do ethics matter in purchase behaviour? Journal of consumer marketing, 18(7):560-577.

CARTER, C.A. \& GRUĖRE, G.P. 2003. Mandatory labeling of genetically modified foods: does it really provide consumer choice? AgBioForum, 6(1 \& 2):68-70.

COWBURN, G. \& STOCKLEY, L. 2005. Consumer understanding and use of nutrition labelling: a systematic review. Public health nutrition, 8(1):21-28.

CROFT, D. 2004. Shopping with attitude: how citizen-consumers are behind a radial overhaul of the Co-op Brand. European retail digest, 42:38-41. Available: Business Source Premier.

DAVIES, S. 2000. Consumers' Association: "Better food labeling" initiative. http://www.which.net/campaigns/food/labelling/0003betterffoodlabellingcresp.pdf Date of access: 20 Feb. 2006.

DE PELSMACKER, P., JANSSENS, W., STERCKX, E. \& MIELANTS, C. 2005. Consumer preferences for the marketing of ethically labelled coffee. International marketing review, 22(5):512-530.

DEPARTMENT OF HEALTH see SOUTH AFRICA. Department of Health

DICKS, E.G. 2007. A model of consumers' perceptions of food additives and consequent purchasing behaviour. Potchefstroom: North-West University. (Ph.D. thesis.) 
DIMARA, E. \& SKURAS, D. 2005. Consumer demand for informative labeling of quality food and drink products: a European Union case study. Journal of consumer marketing, 22(2):90-100.

DRICHOUTIS, A.C., LAZARIDIS, P. \& NAYGA, R.M. 2006. Consumers' use of nutritional labels: a review of research studies and issues. Academy of marketing science review, 9:[ii], 1-22.

EARLY, R. 2002. Food ethics: a decision making too for the food industry? International journal of food science and technology, 37(4):339-349.

FLOWERDEW, D.W. 2000. Declaration of ingredients and additives: European Union. (In Blanchfield, J.R., ed. Food labelling. Cambridge: Woodhead. p. 65-80.)

FOOD STANDARDS AGENCY. 2004. Guidance notes on the Food Safety Act 1990 (Amendment) Regulations 2004 and the General Food Regulations 2004. (FSA.01688.) http://new.wales.gov.uk/ecolidocuments/FSA/FSA. 06188.pdf Date of access: 5 Jun. 2009.

FORD, G.T., HASTAK, M., MITRA, A. \& RINGOLD, D.J. 1996. Can consumers interpret nutrition information in the presence of a health claim? A laboratory investigation. Journal of public policy and marketing, 15(1):1627.

FREWER, L.J., HOWARD, C., HEDDERLEY, D. \& SHEPHERD, R. 1996. What determines trust in information about food-related risks? Underlying

FSA psychological constructs. Risk analysis, 16(4):473-486.

\section{see FOOD STANDARDS AGENCY}

GARRETSON, J.A. \& BURTON, S. 2000. Effects of nutrition facts panel values, nutrition claims, and health claims on consumer attitudes, perceptions of disease-related risks, and trust. Journal of public policy and marketing, 19(2):213-227.

GRUNERT, K.G. 2002. Current issues in the understanding of consumer food choice. Trends in food science and technology, 13(8):275-285.

HIGGINSON, C.S., RAYNER, M.J., DRAPER, S. \& KIRK, T.R. 2002. The nutrition label: which information is looked at? Nutrition and food science, 32(3):92-99.

HORNBY, A.S., ed. 2005. Oxford Advanced Learner's Dictionary of Current English. 7th ed. Oxford: Oxford University Press.

JOSHI, P., MODIFI, S. \& SICHERER, S.H. 2002. Interpretation of commercial food ingredient labels by parents of food-allergic children. Journal of allergy and clinical immunology, 109(6):1019-1021.

KAUFMAN, M. 2001. Consumers want engineered food labeled: shoppers express "outrage" that product choices aren't clear; FDA reports. The Washington Post: 13 Feb. http://www.commondreams.org/headlines01/ 0213-01.htm Date of access: 5 Jun. 2009.

KELLER, S.B., LANDRY, M., OLSON, J., VELLIQUETTE, A.M., BURTON, S. \& ANDREWS, J.C. 1997. The effects of nutrition package claims, nutrition facts panels, and motivation to process nutrition information on consumer product evaluations. Journal of public policy and marketing, 16(2):256269.

KLEIN, R. 2005. A South African study of consumers' perceptions of food labels and its relevance to their purchasing behaviour. Potchefstroom: NorthWest University. (M.Consumer Sciences dissertation.) 
LAZAROWICZ, M. 2005. It's vital we know what we're eating: better food labelling and more information for consumers is crucial and long overdue. Evening news: 1 Apr. http://edinburghnews.scotsman.com/fooddye cancerscare/lts-vital-we-know-what.2614795.jp Date of access: 5 Jun. 2009.

LIAKOPOULOS, M. \& SCHROEDER, D. 2003. Trust and functional foods. New products, old issues. Poiesis and praxis, 2(1):41-52.

LINDLEY, D. 2007. Imperfect information for consumers. Consumer policy review, 17(3):74-79.

MACANDA, P. 2005. Misleading food labels may soon be outlawed: the health department has proposed new regulations to protect consumers. Daily dispatch: 12, 19 Nov. http://www.dispatch.co.za/2005/11/19/Business/ b1.html Date of access: 5 Jun. 2009.

MANNELL, A., BREVARD, P., NAYGA, R. Jr., COMBRIS, P., LEE, R. \& GLOECKNER, J. 2006. French consumers' use of nutrition labels. Nutrition and food science, 36(3):159-168.

MAZIS, B.M. \& RAYMOND, M.A. 1997. Consumer perceptions of health claims in advertisements and on food labels. The journal of consumer affairs, 31(1):10-26.

MCCULLOUGH, J. \& BEST, R. 1980. Consumer preferences for food label information: a basis for segmentation. The journal of consumer affairs, 14(1):180-192.

MCLAREN, A. 1995. Ethical aspects of the labelling of foods derived from modern biotechnology. Opinion of the Group of Advisers on the Ethical Implications of Biotechnology to the European Commission: 5, 5 May. http://ec.europa.eu/european_group_ethics/docs/opinion5_en.pdf Date of access: 4 Jun. 2009.

MEPHAM, T.B. 2000. The role of food ethics in food policy. Proceedings of the Nutrition Society, 59(4):609-618.

MOHR, L.A., WEBB, D.J. \& HARRIS, K.E. 2001. Do consumers expect companies to be socially responsible? The impact of corporate social responsibility on buying behavior. The journal of consumer affairs, 35(1):45-72.

NILSSON, H., TUNÇER, B. \& THIDELL, A. 2003. The use of eco-labeling like initiatives on food products to promote quality assurance: is there enough credibility? Journal of cleaner production, 12:517-526.

PARKER, A.R. \& PENFIELD, M.P. 2005. Labelling of vanilla type affects consumer perception of vanilla ice cream. Journal of food science, 70(8):553-557.

PETRUCCELLI, P.J. 1996. Consumer and marketing implications of information provision: the case of Nutrition Labeling and Education Act of 1990. Journal of public policy and marketing, 15(1):150-153.

PRZYREMBEL, H. 2004. Food labelling legislation in the EU and consumer information. Trends in food science and technology, 15:360-365.

RADAS, S., TEISL, M.F. \& ROE, B. 2008. An open mind wants more: opinion strength and the desire for genetically modified food labeling policy. The journal of consumer affairs, 42(3):335-361.

RENN, O. 2005. Risk perception and communication: lessons for the food and food packaging industry. Food additives and contaminants, 22(10):10611071. 
SA

see SOUTH AFRICA

SCHIFFMAN, L.G. \& KANUK, L.L. 2009. Consumer behavior. 9th ed. Upper Saddle River: Prentice Hall.

SCHLOSSER, E. 2002. The bitter truth about fast food. The Guardian, 7 Apr. http://www.guardian.co.uk/books/2001/apr/07/features.weekend Date of access: 5 Jun. 2009.

SCHOLDER ELLEN, P. \& FITZGERALD BONE, P. 2008. Stained by the label? Stigma and the case of genetically modified foods. Journal of public policy and marketing, 27(1):69-82, Spring.

SHANNON, B. 1993. Nutrition labelling: putting the consumer first. British food journal, 96(4):40-44.

SHAW, D. \& CLARKE, I. 1999. Belief formation in ethical consumer groups: an exploratory study. Marketing intelligence and planning, 17(2):109-120.

SIJTSEMA, S., LINNEMANN, A., VAN GAASBEEK, T., DAGEVOS, H. \& JONGEN, W. 2002. Variables influencing food perception reviewed for consumer-orientated product development. Critical reviews in food science and nutrition, 42(6):565-582.

SILAYOI, P. \& SPEECE, M. 2004. Packaging and purchase decisions: an exploratory study on the impact of involvement level and time pressure. British food journal, 106(8):607-628.

SILVERGLADE, B.A. 1996. The Nutrition Labeling and Education Act: progress to date and challenges for the future. Journal of public policy and marketing, 15(1):148-150.

SOUTH AFRICA. 2007. Foodstuffs, Cosmetics and Disinfectants Act 54 of 1972: Regulations relating to the labelling and advertising of foodstuffs. (Proclamation No. R. 642, 2007.) Government gazette, 30075:129-145, 20 Jul. (Regulation gazette no. 8718.)

SOUTH AFRICA. Department of Health. 2007. Draft food labelling regulations to improve healthy lifestyle. http://www.doh.gov.za/docs/pr/2007/pr07 26a.html Date of access: 5 Jun. 2009.

TEISL, M.F., HALVERSON, L., O'BRIEN, K., ROE, B., ROSS, N. \& VAYDA, M. 2002. Focus group reactions to genetically modified food labels. AgBioForum, 5(1):6-9.

TURNER, A. 2007. The development of food labelling regulations in the UK. British nutrition foundation nutrition bulletin, 32(2):161-167.

US FOOD AND DRUG ADMINISTRATION. 2001. Guidance for industry: voluntary labelling indicating whether foods have or have not been developed using bioengineering. http://www.foodsafety.gov/ dms/ biolabgu.html Date of access: 5 Jun. 2009.

USFDA

see US FOOD AND DRUG ADMINISTRATION

UUSITALO, O. \& OKSANEN, R.M. 2004. Ethical consumerism: a view from Finland. International journal of consumer studies, 28(3):214-221.

VILJOEN, C.D., DAJEE, B.K. \& BOTHA, G.M. 2006. Detection of GMO in food products in South Africa: implications of GMO labelling. African journal of biotechnology, 5(2):73-82. 
VOORDOUW, J., CORNELISSE-VERMAAT, J.R., YIAKOUMAKI, V., THEODORIDIS, G., CHRYSSOCHOIDIS, G. \& FREWER, L.J. 2009. Food allergic consumers' preferences for labelling practices: a qualitative study in a real shopping environment. International journal of consumer studies, 33(1):94-102.

WANDEL, M. 1997. Food labelling from a consumer perspective. British food journal, 99(6):212-219.

WANG, G., FLETCHER, S.M. \& CARLEY, D.H. 1995. Consumer utilization of food labeling as a source of nutrition information. The journal of consumer affairs, 29(2):368-380.

WILKENING, V. 1996. US labelling. Food industries of South Africa: 10, Jan.

WRIGHT, L.T. 1997. Exploring the need for extended research: an investigation of consumer attitudes to product labelling. Journal of product and brand management, 6(6):417-427.

ZADEK, S., LINGAYAH, S. \& FORSTATER, M. 1998. Social labels: tools for ethical trade. Brussels: New Economics Foundation. Final report. http://www.ilo.org/dyn/basi/docs/F126/social_labels_tools.pdf Date of access: 5 Jun. 2009.

Key concepts:

consumer

consumer education

food ethics

food labelling

Kernbegrippe:

verbruiker

verbruikersopvoeding

voedseletiek

voedseletikettering 